\title{
Formation and characterization of acid mine drainage in the Madzharovo ore field, Southeastern Bulgaria
}

Svetlana Bratkoval

${ }^{1}$ University of Mining and Geology "St. Ivan Rilski", Sofia;

e-mail: s_bratkova@mgu.bg

\section{Формиране и характеристика на кисели руднични води в Маджаровското рудно поле, Югоизточна България}

\section{Светлана Браткова}

Bratkova, S. 2021. Formation and characterization of acid mine drainage in the Madzharovo ore field, Southeastern Bulgaria. Engineering Geology and Hydrogeology, 35, 41-50.

\begin{abstract}
The formation of acid mine drainage (AMD) is a serious environmental problem in areas with mining and processing industries worldwide. Their generation is associated with chemical and biological processes of oxidation of sulfide minerals, mainly pyrite. Sources of AMD can be deposits of sulfide minerals and coal with a high content of pyrite sulfur, mining waste and some tailings. The impact of AMD on surface and groundwater in mining areas continues for decades after the cessation of extraction. An example of the negative impact of generated acid mine drainage on the state of surface waters is in the region of Madzharovo. Years after the cessation of mining, the waters at the discharge points "Momina Skala", "Harman Kaya" and "Pandak Dere" are characterized by low pH values and high concentrations of iron, copper, zinc, cadmium, lead and manganese.
\end{abstract}

Keywords: acid mine waters, heavy metals, closed mines.

Резюме. Формирането на кисели руднични води (КРВ) е тежък екологичен проблем в районите с минно-добивен и преработвателен отрасъл в световен мащаб. Генерирането им е свързано с протичане на химични и биологични процеси на окисление на сулфидните минерали, главно на пирита. Източници на КРВ могат да бъдат находища на сулфидни минерали и въглища с високо съдържание на пиритна сяра, минни отпадъци и някои хвостохранилища. Въздействието на КРВ върху повърхностните и подземните води в райони с минно-добивна дейност продължава десетки години след прекратяване на добива. Пример за негативното въздействие на генерирани кисели руднични води върху състоянието на повърхностни води е районът на Маджарово. Години след преустановяване на рудодобива, водите в точките на заустване Участьк „Момина скала", Участък „Харман кая" и Участък „Пандък дере" се характеризират с ниски стойности на $\mathrm{pH}$ и високи концентрации желязо, мед, цинк, кадмий, олово и манган.

Ключови думи: кисели руднични води, тежки метали, прекратен рудодобив. 


\section{Въведение}

Един от най-тежките екологични проблеми в световен мащаб е генерирането на кисели руднични води (КРВ). Формирането им се дължи на биологично и химично окисление на сулфидни минерали (пирит, халкопирит, сфалерит, галенит, арсенопирит) при контакт на рудна маса, въглища с високо съдържание на пиритна сяра и минерални отпадъци с въздух и вода (Luther, 1987; Acharya and Kharel, 2020). Протичането на вторични реакции като разтваряне на карбонатни и окисни минерали, неутрализация и йонен обмен води до вариране на състава на КРВ от такива с висока киселинност и съдържание на Fe, Mn, Al, As, цветни метали $(\mathrm{Cu}, \mathrm{Zn}, \mathrm{Cd}, \mathrm{Co}, \mathrm{Ni})$ и сулфати до слабо кисели и неутрални води, съдържащи ниски концентрации желязо, наличие на цветни метали и високо сулфатно съдържание (Sheoran and Sheoran, 2006; Brown, 2010; Cravotta, 2010; Wang et al., 2021).

В рудите със сулфидна минерализация най-разпространеният сулфиден минерал е пиритът $\left(\mathrm{FeS}_{2}\right)$. В началния етап на процеса на минната дейност протича слаба, спонтанна реакция на пирита с молекулния кислород (Borden, 2001; Jennings et al., 2008):

$$
\mathrm{FeS}_{2}+3,5 \mathrm{O}_{2}+\mathrm{H}_{2} \mathrm{O} \rightarrow \mathrm{Fe}^{2+}+2 \mathrm{SO}_{4}^{2-}+2 \mathrm{H}^{+}
$$

При първоначалните неутрални стойности на $\mathrm{pH}$ на средата $\mathrm{Fe}^{2+}$ много бързо се окислява до ферийони, които хидролизират с водата. Продукти на реакцията са ферихидроксид и протони:

$$
\mathrm{Fe}^{3+}+3 \mathrm{H}_{2} \mathrm{O} \rightarrow \mathrm{Fe}(\mathrm{OH})_{3}+3 \mathrm{H}^{+}
$$

В началния етап на добива на минерални суровини в рудната маса и дренажните води се установяват в големи количества неутрофилни тионови хемолитотрофни бактерии (Thiobacillus thioparus и др.). Източник на енергия за тези микроорганизми са редуцирани съединения на сярата, в това число сулфидните минерали галенит $(\mathrm{PbS})$, бисмутин $\left(\mathrm{Bi}_{2} \mathrm{~S}_{3}\right)$, антимонит $\left(\mathrm{Sb}_{2} \mathrm{~S}_{3}\right)$ и пиротин (FeS) (Vidyalakshmi, 2009).

Процесите на химично и микробиологично окисление на сулфидните минерали водят до генериране на $\mathrm{H}_{2} \mathrm{SO}_{4}$. Във времето $\mathrm{pH}$ на средата спада под 4 и се създават благоприятни условия за развитието на ацидофилните хемолитотрофни бактерии (Acidithiobacillus ferrooxidans, L. ferrooxidans, A. thiooxidans и др.) (Ehrlich, 2001).

Двувалентното желязо в кисела среда $(\mathrm{pH}<3)$ е относително стабилно в присъствието на кислород. Окисление на феройоните до ферийони обаче протича с висока скорост в зони с ниски стойности на $\mathrm{pH}$, поради факта, че $\mathrm{Fe}^{2+} \mathrm{e}$ предпочитан източник на енергия от ацидофилните бактерии $A$. ferrooxidans и $L$. ferrooxidans (реакция 3) (Banfield and Nealson, 1997; Yang et al., 2007):

$$
4 \mathrm{FeSO}_{4}+\mathrm{O}_{2}+2 \mathrm{H}_{2} \mathrm{SO}_{4} \rightarrow 2 \mathrm{Fe}_{2}\left(\mathrm{SO}_{4}\right)_{3}+2 \mathrm{H}_{2} \mathrm{O}
$$

При $\mathrm{pH}$ около 2-3 скоростта на бактериалното окисление на $\mathrm{Fe}^{2+}$ е около 500000 пъти по-висока от тази при химичното окисление.

Директното окисление на пирита и останалите сулфидни минерали от ацидофилните хемолитотрофни бактерии може да се представят със следните стехиометрични реакции (4 и 5):

$$
\begin{aligned}
& 4 \mathrm{FeS}_{2}+15 \mathrm{O}_{2}+2 \mathrm{H}_{2} \mathrm{O} \rightarrow 2 \mathrm{Fe}_{2}\left(\mathrm{SO}_{4}\right)_{3}+2 \mathrm{H}_{2} \mathrm{SO}_{4} \\
& \mathrm{MS}+\mathrm{O}_{2}+2 \mathrm{H}_{2} \mathrm{SO}_{4} \rightarrow \mathrm{MSO}_{4}+2 \mathrm{H}_{2} \mathrm{O}+2 \mathrm{~S}^{\circ}
\end{aligned}
$$

където $\mathrm{M}$ е $\mathrm{Cu}, \mathrm{Pb}, \mathrm{Zn}, \mathrm{Cd}$ и т.н 
Микробно генерираните $\mathrm{Fe}^{3+}$ са силен окислител и при тези ниски стойности на $\mathrm{pH}$ реагират с по-големи количества пирит и други сулфидни минерали, окислявайки сулфидната сяра до сулфат (реакции 6 и 7):

$$
\begin{aligned}
& \mathrm{FeS}_{2}+14 \mathrm{Fe}^{3+}+8 \mathrm{H}_{2} \mathrm{O} \rightarrow 15 \mathrm{Fe}^{2+}+2 \mathrm{SO}_{4}^{2-}+16 \mathrm{H}^{+} \\
& \mathrm{MS}+\mathrm{Fe}_{2}\left(\mathrm{SO}_{4}\right)_{3} \rightarrow \mathrm{MSO}_{4}+2 \mathrm{FeSO}_{4}+\mathrm{S}^{\circ}
\end{aligned}
$$

Това е т.н. индиректен механизъм на окисление на сулфидните минерали посредством микробно продуцирани ферийони. Хемолиотрофните бактерии бързо окисляват получените феройони до $\mathrm{Fe}^{3+}$, които от своя страна отново реагират с пирита и другите метални сулфиди. Протичането на тези реакции води до бързо, прогресивно увеличаване на скоростта на окисление на сулфидните минерали и повишаване на концентрацията на тежките метали в киселите руднични води.

КРВ, генерирани от находищата на сулфидни минерали, депа за минерални отпадъци и някои хвостохранилища, контактуват и разтварят други минерални компоненти на скалите (España, 2008). Тъй като един от основните скалообразуващи елементи е алуминият, киселите дренажни води могат да го съдържат и във високи концентрации.

Контактьт на КРВ с манганови карбонатни минерали, например родохрозит $\left(\mathrm{MnCO}_{3}\right)$, води до разтваряне на минерала и постъпване на манган във водите:

$$
\mathrm{MnCO}_{3}+2 \mathrm{H}^{+} \rightarrow \mathrm{Mn}^{2+}+\mathrm{H}_{2} \mathrm{O}+\mathrm{CO}_{2}
$$

Обикновено доминираща група микроорганизми в киселите руднични води са ацидофилни хемолитотрофни бактерии A. ferrooxidans, A. thiooxidans и $L$. ferrooxidans, като те могат да съжителстват и с факултативни хетеротрофи като Sulfobacillus spp (Bernardez et al., 2021). Числеността на микробните популации обаче може да варира както пространствено, така и сезонно (Johnson и Hallberg, 2005; Luptakova et al., 2012).

При ниски стойности на $\mathrm{pH}$ тежките метали са много добре разтворими и мобилни, поради което могат да бъдат транспортирани на големи разстояния от източника на замърсяване и да имат отрицателен ефект върху качеството на повърхностните и подземните води (McCarthy, 2011; Zhang et al., 2019). Киселите дренажни води имат негативно влияние и върху почвите, което се изразява в намалена микробна биомаса, отрицателно въздействие върху процесите на въглеродна минерализация и трансформациите на азота, почвената ензимна активност и продуктивността на растенията (Munyai et al., 2021).

Обект на настоящото проучване е състоянието на повьрхностните води в района на Маджарово. Години след преустановяване на рудодобива, водите в точките на заустване (Участък „Момина скала“, Участьк „Харман кая“ и Участък „Пандък дере”) рудничните води се характеризират с високи концентрации желязо, мед, цинк, кадмий, олово и манган.

\section{Обект на изследване}

Маджаровското рудно поле е било обект на експлоатация от минното предприятие "Маджарово“ ЕАД в периода между 1958 и 1997 г. Отработвани са запасите от оловно-цинкови руди, групирани в няколко по-големи производствени участъка - у-к „Арда“, у-к „Харман кая, у-к „Момина скала“, у-к „Брусевци“. Прилаганата система на добив е довела до формирането на големи празни пространства под земната повърхност и до топографски изменения на терена (обрушовки, пропадания и др.). Производствената дейност на "Маджарово“"ЕАД е прекратена през 1997 г. Ликвидацията на минните участьци е извършена по утвърдени проекти за ликвидиране на последствията върху околната среда, изготвени от НИПРОРУДА. През 2007-2008 г. е предложен идеен проект за изграждане на 
пречиствателна станция, в която да се пречистват замърсените руднични води. Проектът не е реализиран, тъй като е преценено, че след затваряне (запечатване) на повърхностните изходи на минните изработки и ограничаване на достъпа на кислород, концентрациите на съдържащите се в рудничните води разтворими форми на тежките метали рязко ще спаднат. След 2012 г., пробонабиране и анализ на водни проби от двете хвостохранилища и от участьци Пандък дере, Момина скала, Харман кая и Брусевци е извършван от „Екомедет“ ЕООД. От края на 2017 година „Еко Антрацит“ ЕАД е правоприемник на „Екомедет“ ЕООД.

Обект на настоящето изследване са три пункта на повърхностни води, разположени в Маджаровското рудно поле, съответно Пункт №1 - след карбонатен филтьр участьк „Момина скала $2^{6}$, с географски координати N $41^{\circ}$ $38^{\prime} 28^{\prime \prime}$ и Е 25 50' 53", Пункт №2 - след карбонатен филтър участък „Харман

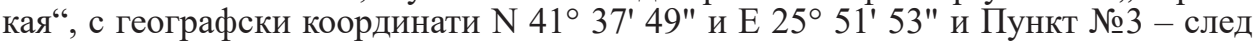
карбонатен филтър участьк „Пандък дере“, с географски координати $\mathrm{N} 41^{\circ} 39^{\prime}$ $05^{\prime \prime}$ и Е 25 52' 17", представени на фиг. 1 и фиг. 2.

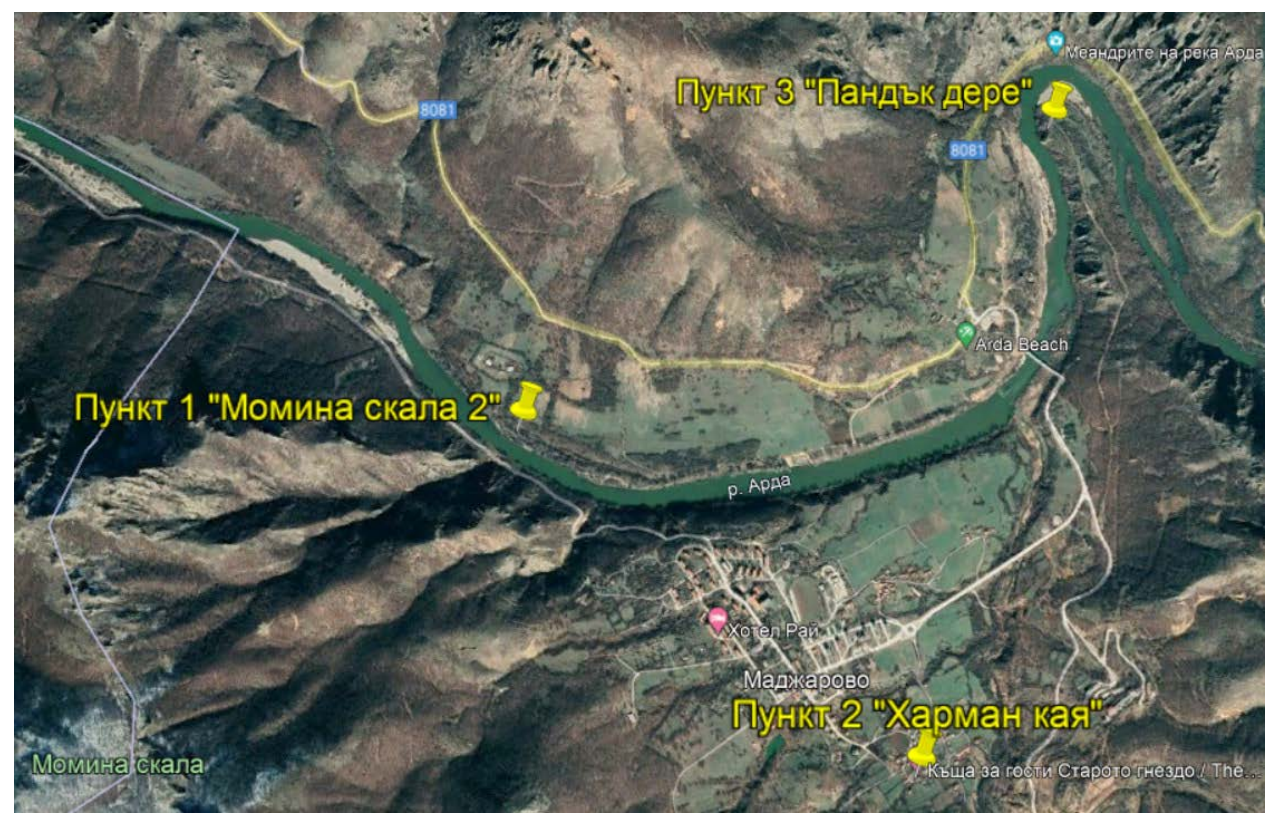

Фиг. 1. Местоположение на пунктовете „Момина скала 2“, „Харман кая““ и „Пандък дере“в Маджаровското рудно поле.

Fig. 1. Location of the monitoring points "Momina Skala 2", "Harman Kaya" and "Pandak Dere" in the Madzharovo ore field.

\section{Материали и методи}

Пробонабирането на водни проби и тяхното консервиране е извършено сьгласно ISO 5667. Активната реакция на водите е измервана с $\mathrm{pH}$ метър WTW Multi 340i/ SET. Концентрацията на тежки метали във водите е определяна чрез ICP-AES. Допълнителна информация от провеждан собствен и контролен мониторинг по показателите $\mathrm{pH}, \mathrm{Fe}, \mathrm{Mn}, \mathrm{Zn}, \mathrm{Cu}, \mathrm{Pb}, \mathrm{Cd}$, и $\mathrm{Ni}$ на водите от трите пункта е предоставена от Басейнова дирекция Източно-беломорски район. Данните са обработени с програмата Excel. 

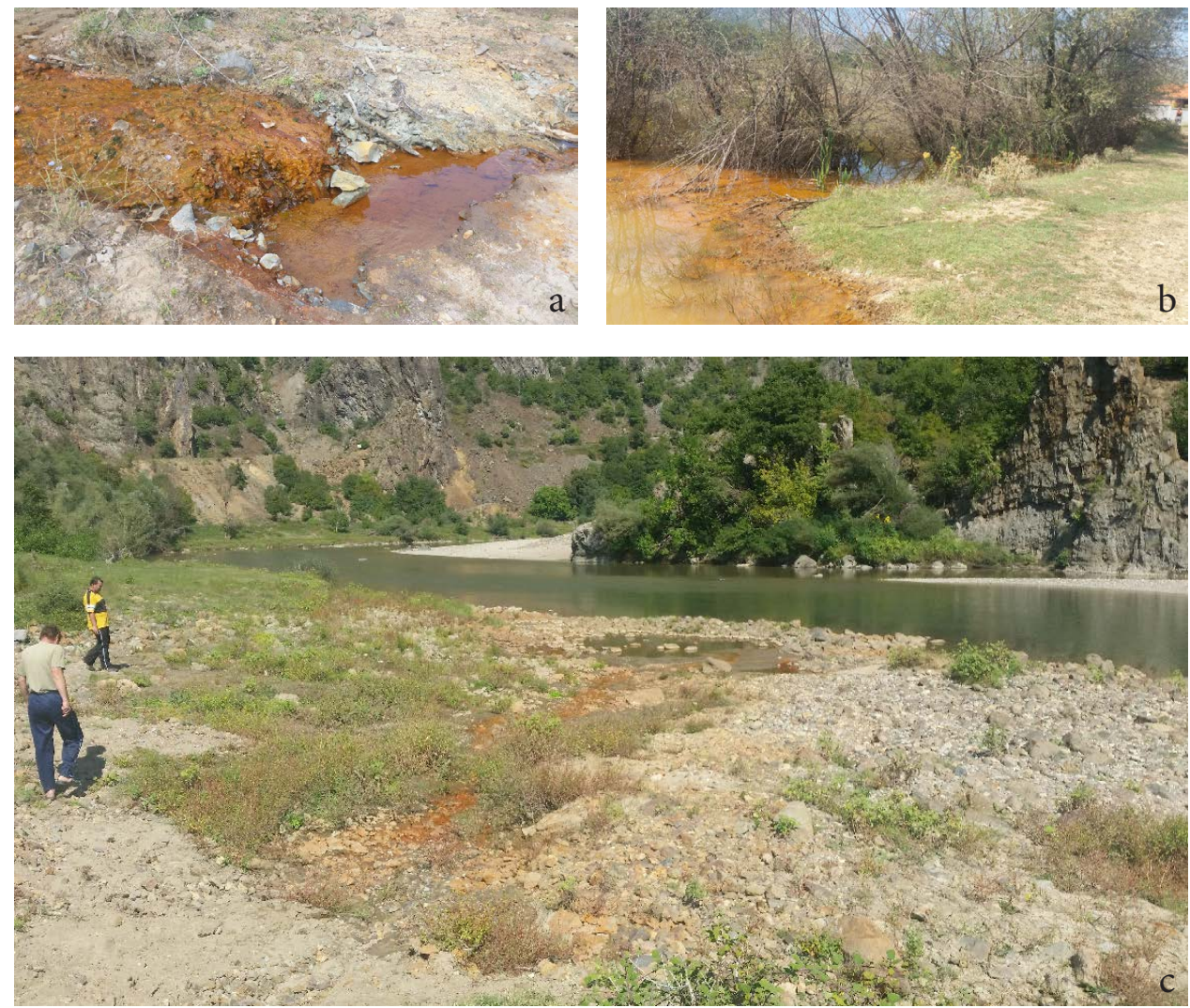

Фиг. 2. Формирани руднични води от трите пункта: а) води от участък „Момина скала 2“; b) води от участък „Харман кая“ и с) води от участък „Арда“, стичащи се по „Пандък дере” в река Арда.

Fig. 2. Formed mine waters from the three points: a) waters from the section "Momina Skala 2"; b) waters from the Harman Kaya section and c) waters from the Arda section flowing down the Pandak Dere in the Arda River.

\section{Резултати}

Резултатите от проведения в рамките на настоящото изследване проучвателен мониторинг върху повърхностните води от трите пункта в района на обекта, както и данните от собствения и контролния мониторинг, показват значителни отклонения от индивидуалните емисионни ограничения (ИЕО) на показателите $\mathrm{pH}, \mathrm{Fe}, \mathrm{Mn}, \mathrm{Zn}, \mathrm{Cu}, \mathrm{Pb}$ и $\mathrm{Cd}$ (фиг. 3).

Данните, представени на фиг. За, показват значителни отклонения на показателя $\mathrm{pH}$ на водите от трите пункта (ИЕО е в границите между 6 и 9). Независимо, че формираните руднични води преминават през карбонатен филтьр, с малки изключения през периода 2001 - 2020 г., водите от участьци „Момина скала 2” и „Пандък дере” се характеризират със стойности на рН в интервала от 3 до 6. Активната реакция на водите от участьк „Харман кая” с изключение на периода 2003 - 2006 г. е над 6.

Желязото е един от ключовите замърсители в рудничните води вследствие окислението на пирита. През периода от 2001-2010 г. Fe в дренажните води от трите участька най-често е в диапазона от 10 до $58 \mathrm{mg} / \mathrm{L}$, като във водите от „Пандък дере” през 2003 и 2007 г. са измерени по-високи концентрации, съответно 125,79 и 72,63 mg/L (фиг. 3b). През периода от 2010 до 2020 г. проблемът с високите концентрации на желязото е най-тежък в участък „Харман кая”, в 

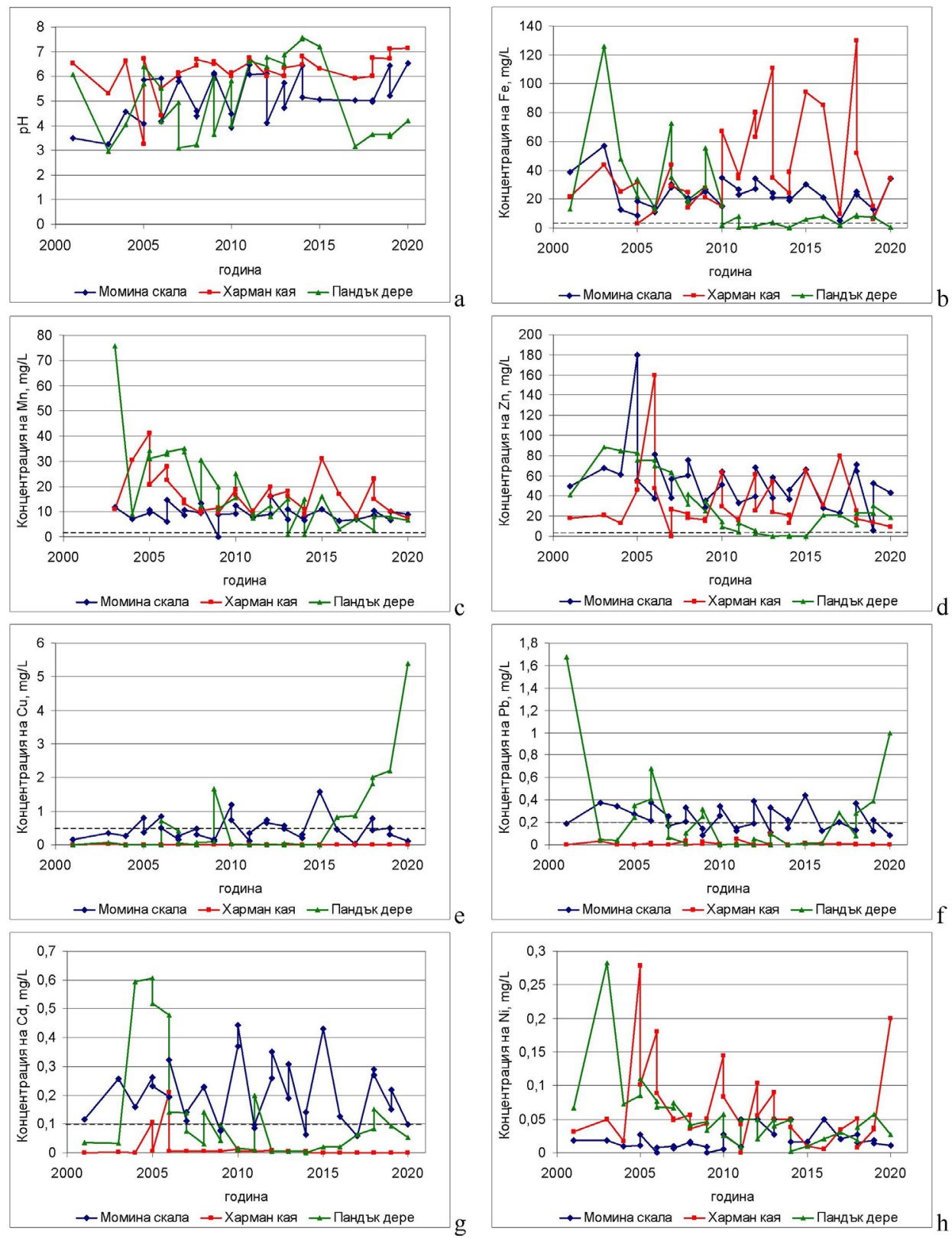

Фиг. 3. Стойности на а) pH и концентрация на b) желязо; с) манган; d) цинк; е) мед: f) олово; g) кадмий и h) никел в трите пункта за периода 2001-2020 г. ИЕО е представено с пунктирана линия.

Fig. 3. Values of a) $\mathrm{pH}$ and concentration of b) iron; c) manganese; d) zinc; e) copper: f) lead; g) cadmium and h) nickel at the three points for the period 2001-2020. The Individual Emission Limit is represented by a dotted line.

който при $1 / 2$ от измерванията е установено съдържание на Fe в диапазона от 40 до $130 \mathrm{mg} / \mathrm{L}$. В същия период водите от участък „Пандък дере” се характеризират с желязо в концентрации от 0,7 до 8,2 mg/L, като ИЕО от 3,5 mg/L са превишени в болшинството от случаите. 
През целия период на мониторинг във водите от трите пункта е установено и превишаване на съдържанието на манган (ИЕО 0,8 mg/L). Резултатите, представени на фиг. 3c, показват, че концентрацията на мангана много често е в интервала 6 - $35 \mathrm{mg} / \mathrm{L}$, като по-високите стойности са типични за пунктовете „Харман кая” и „Пандък дере”.

Друг замърсител в рудничните води от Маджаровското рудно поле е цинкът (фиг. 3d). При ИЕО от $2 \mathrm{mg} / \mathrm{L}$ през двадесетгодишния период на мониторинг, цинкът във водите от трите пункта е в концентрации от 13 до 179,78 mg/L. Два пика, съответно през 2005 и 2006 г., са измерени в участьк „Момина скала 2” и „Харман кая”. През периода от 2005 до 2015 г. са установени тенденции към намаляване на концентрацията на цинка в „Пандък дере”, но след 2015 г. съдържанието на замърсителя във водите отново се повишава и е в интервала от 10 до $30 \mathrm{mg} / \mathrm{L}$.

На фиг. 3е и фиг. 3f са показани концентрациите на мед и олово за двадесетгодишния мониторингов период. Докато в рудничните води от участък „Харман кая” концентрациите на Сu и Pb не надвишават ИЕО, съответно 0,5 и 0,2 $\mathrm{mg} / \mathrm{L}$, двата замърсителя често се установяват във водите от пунктовете „Момина скала” и „Пандък дере”, като за последния пункт е обезпокоителна тенденцията към увеличаване на концентрациите на замърсителите през последните 4 години.

Значителни отклонения от ИЕО $(0,1 \mathrm{mg} / \mathrm{L})$ са наблюдавани по отношение съдържанието на кадмий в рудничните води главно от участък „Момина скала” и „Пандък дере” (фиг. 3g). В периода след 2006 г. концентрацията на Сd във водите на „Харман кая” са под $0,0005 \mathrm{mg} / \mathrm{L}$.

Не е установено превишение над ИЕО $(0,5 \mathrm{mg} / \mathrm{L})$ на концентрацията на никел в трите пункта през мониторинговия период.

\section{Дискусия}

Генерирането на КРВ е следствие на химична и биологична окислителна деструкция на сулфидните минерали. Получените данни от двадесетгодишния мониторинг на водите от трите пункта показват, че в района протичат процеси, водещи до формиране на дренажни води с ниски стойности на рН и високи концентрации сулфати, тежки метали ( $\mathrm{Fe}, \mathrm{Cu}, \mathrm{Zn}, \mathrm{Mn}, \mathrm{Al}, \mathrm{Cd}$ и др.). Трябва да се отбележи, че ИЕО на показателите $\mathrm{Fe}, \mathrm{Mn}, \mathrm{Zn}, \mathrm{Cu}, \mathrm{Pb}, \mathrm{Cd}$, и $\mathrm{Ni}$ са значително по-високи, в сравнение със стандарта за качество на химични елементи и други вещества, посочени в НАРЕДБА за стандарти за качество на околната среда за приоритетни вещества и някои други замърсители и в приложение 7 към НАРЕДБА № Н-4 от 14.09.2012 г.

Процесите на окисление на сулфидни минерали продължават и след ликвидацията на минните участъци в Маджаровското рудно поле. Използването единствено на карбонатни филтри за третиране на генерираните руднични води не е ефективно, най-вероятно поради пасивирането на неутрализационния агент от формирани ферихидроксиди.

Разликите в съдържанието на тежки метали в трите пункта доказват наличие на множество неорганизирани потоци на дренажни води, преминаващи през рудни тела с различна минерализация. Влияние върху химичния състав на повърхностните руднични води оказва и мащабния подземен поток, дрениращ в терасата на р. Арда (Stoyanov et al., 2019). Подземният поток е насочен от старите минни изработки към речната тераса. Това създава условия за възходящи потоци, които отвеждат рудничните води към повърхността.

Ниските стойности на $\mathrm{pH}$ са предпоставка за разпространение на тежките метали на далечни разстояния от източника на замърсяване. Данните от мониторинга не показват тенденции към стабилизиране на стойностите на pH в диапазона от 6 до 9 и намаляване на концентрациите на замърсителите. 
Очаква се, че ако не бъдат предприети мерки, процесите на формиране на кисели дренажни води в Маджаровското рудно поле да продължат десетилетия напред.

Резултатите от изследванията върху състава и качествата на рудничните води у нас през последните години са много добра основа за разработване на хидрогеоложки модели за оценка и прогноза на замърсяването на повърхностните и подземните води в райони с минно-добивна дейност (Kolev and Hristov, 2018; Benderev et al., 2020; Gerginov et al., 2020; Hristov et al., 2020; Mihaylova et al., 2019, 2021; Plochev and Zeinelov, 2020; Stoyanov et al., 2018, 2019; 2021, Stoyanov, 2019).

\section{Изводи}

Въз основа на мониторинг на три пункта от точките на заустване на Участък „Момина скала“, Участък ,Харман кая“ и Участьк „Пандък дере” могат да бъдат направени следните изводи:

- Приложението единствено на карбонатни филтри за третиране на генерираните руднични води не е ефективно по отношение неутрализиране на $\mathrm{pH}$ на водите;

- Рудничните води се характеризират с високи концентрации желязо, мед, цинк, кадмий, олово и манган;

- Има наличие множество неорганизирани потоци на дренажни руднични води, но пълна и цялостна картина за дебит, химичен състав и локализация липсва;

- Необходимо е предприемането на пречистване на повърхностните води от рудниците „Момина скала 1 и 2”, рудник „Харман кая”, рудник „Арда (Пандък дере). Изборът на начин на пречистване - пречиствателна станция за руднични води, изграждане на „влажна зона” или семи-пасивно (комбинирано) третиране изисква задълбочен анализ на количествените и качествените характеристики на рудничните води.

\section{Благодарности}

Статията се базира на непубликувани авторски разработки, изпълнени в рамките на Националната научна програма „Опазване на околната среда и намаляване на рисковете от нежелани събития и природни бедствия“, одобрена с Решение на Министерския съвет № 577/17.08.2018 г. и подкрепена от Министерството на образованието и науката, Р България (Споразумение № DO-230 / 06-12-2018). В статията са използвани данни от проект EARBDMINING „Проучвателен мониторинг за оценка на натиска и въздействието от рудодобив и рудопреработка на метални руди и уранодобив и предложения за мерки към ПУРБ в ИБР”. Авторът изказва благодарност на Басейнова дирекция Източно-беломорски район за любезното съдействие и предоставяне на мониторингови данни за периода 2015 - 2020 г.

\section{Използвани нормативни документи: Used legislation Documents}

НАРЕДБА № Н-4 от 14.09.2012 г. за характеризиране на повърхностните води, последно изм. и доп. ДВ, бр. 79 от 23.09.2014 г.

НАРЕДБА за стандарти за качество на околната среда за приоритетни вещества и някои други замърсители, Приета с ПМС № 256 от 1.11.2010 г., последно изм. и доп. ДВ, бр. 97 от 11.12.2015 г. 


\section{Литература:}

\section{References}

Acharya, B. S., G. Kharel. 2020. Acid mine drainage from coal mining in the United States - An overview. J. Hydrol. 588:125061, https://doi.org/10.1016/j. jhydrol.2020.125061.

Benderev, A., I. Dimitrov, B. Mihailova, V. Hristov, I. Ilieva. 2016. Hydrogeological risk assessment in the Elatsite copper mine, Central Bulgaria. Geologica Balcanica. 45, 65-76.

Bernardez, L. A., L. E. L. de Oliveira, L. R. P. de Andrade Lima. 2021. Acid mine drainage at the Bahia Gold Belt (Brazil): microbial isolation and characterization. Environ. Monit. Assess., 193, 60, https://doi.org/10.1007/s10661-021-08844-2.

Banfield, J.F., K.H. Nealson. 1997. Geomicrobiology: Interactions between Microbes and Minerals. Mineralogical Society of America, Washington, https://doi. org/10.1515/9781501509247.

Borden, R. 2001. Geochemical evolution of sulfide-bearing wast e rock soils at the Bingham Canyon Mine, Utah. Geochemistry: Exploration, Environment, and Analysis, 1, 1, 15-21, https://doi.org/10.1144/geochem.1.1.15.

Brown, A. 2010. Reliable Mine Water Technology. Mine Water Environ, 29, 2, 85-91, https://doi.org/10.1007/s10230-010-0111-7.

Cravotta, C. A. I. 2010. Abandoned Mine Drainage in the Swatara Creek Basin, Southern Anthracite Coalfield, Pennsylvania, USA: 2. Performance of Treatment Systems. Mine Water Environ, 29, 3, 200-216, https://doi.org/10.1007/s10230010-0113-5.

Ehrlich, H. L. 2001. Geomicrobiology. Marcel Dekker, Inc., New York.

España, S. J. 2008. Acid Mine Dr ainage in the Iberian Pyrite Belt: An Overview, Macla 10, 34-43.

Gerginov, P., D. Antonov, A. Benderev, V. Stoyanova, T. Kotsev. 2020. Analysis and prognosis of the aqueous migration of arsenic based on complex study of Ogosta river valley's hydrogeological elements (at specific floodplain site). Comptes rendus de l'Acad'emie bulgare des Sciences, 73, 10, 1409-1415, https://doi. org/10.7546/CRABS.2020.10.10.

Hristov, V., A. Benderev, I. Vasilev, B. Mihaylova, M. Krastanov. 2012. Hydrogeological Condition in Open Pit Mine Ellatsite. Engineering Geology and Hydrogeology, 26, 135-154 (in Bulgarian with English abstract).

Johnson, D.B., K.B. Hallberg. 2005. Acid mine drainage remediation options: a review. Science of the Total Environment, 338, 3-14, https://doi.org/10.1016/j. scitotenv.2004.09.002.

Jennings, S.R., D.R. Neuman, P.S. Blicker. 2008. Acid Mine Drainage and Effects on Fish Health and Ecology: A Review. Reclamation Research Group Publication, Bozeman, MT.

Kolev, S., V. Hristov. 2018. Groundwater rebound in "Druzhba" uranium mine (SW Bulgaria) after cessation of mining activities. - Proceedings of 18th international multidisciplinary scientific geoconference SGEM 2018, Vol. 18, Issue 12, 317324, https://doi.org/10.5593/sgem2018/1.2/S02.040.

Luptakova, A., M. Prascakova, I. Kotulicova. 2012. Occurrence of Acidithiobacillus ferrooxidans Bacteria in Sulfide Mineral Deposits of Slovak Republic, Chemical engineering transactions, 28, 31-36.

Luther, G. W. 1987. Pyrite oxidation and reduction: molecular orbital theory considerations. Geochim CosmochimActa, 51,31939, https://doi.org/10.1016/00167037(87)90127-X. 
McCarthy, T.S., 2011. The impact of acid mine drainage in South Africa. South Afr. J. Sci. 107, 1-7, https://doi.org/10.4102/sajs.v107i5/6.712.

Mihaylova, B., V. Hristov, A. Benderev. 2019. Assessment of groundwater quality before entering the production site of the copper plant "Aurubis Bulgaria" AD. Review of the Bulgarian Geological Society, vol. 80, part 3, 173-175 (in Bulgarian with English abstract).

Mihaylova, B., S. Valchev, A. Benderev, H. Dobrev, K. Dachev, G. Bardarska. 2021. Influence of Medetska River on the pollution of Topolnitsa River. Review of the Bulgarian Geological Society, Vol. 82, Part 3, 204-206 (in Bulgarian with English abstract), https://doi.org/10.52215/rev.bgs.2021.82.3.177.

Munyai, R., H.J.O. Ogola, D.M. Modise. 2021. Microbial Community Diversity Dynamics in Acid Mine Drainage and Acid Mine Drainage-Polluted Soils: Implication on Mining Water Irrigation Agricultural Sustainability. Front. Sustain. Food Syst. 5:701870, https://doi.org/10.3389/fsufs.2021.701870.

Plochev, S., S. Zeinelov. 2020. Pollution of groundwater and surface water from the mining industry, Journal of Mining and Geological Sciences, 63, 89-94.

Sheoran, A.S., V. Sheoran. 2006. Heavy metal removal mechanism of acid mine drainage in wetlands: A critical review, Minerals Engineering, 19, 105-116, https://doi.org/10.1016/j.mineng.2005.08.006.

Stoyanov, N., S. Kolev, V. Petrov. 2018. Prognosis of contaminants mass transport in groundwater after cessation of uranium mining in Momino deposit (South Bulgaria). Proceedings of 18 th international multidisciplinary scientific geoconference SGEM 2018, Vol. 18, Issue 12, 593-600, https://doi.org/10.5593/ sgem2018/1.2/S02.075.

Stoyanov, N., S. Bratkova, S. Dimovski. 2019. Mathematical Models of Contamination with Heavy Metals from the Abandoned Mines in the Madjarovo Ore Field, Eastern Rhodopes, Journal of Mining and Geological Sciences, 62, 1, 83-88.

Stoyanov, N.T. 2019. Mathematical modeling in hydrogeology. Numerical 3D models using finite difference method. Publ. house "V. Nedkov", Sofia, 246 p. (in Bulgarian)

Stoyanov, N., S. Dimovski, S. Kolev. 2021. Groundwater pollution in the Mesta River terrace caused by Eleshnitsa tailings pond - current status. Review of the Bulgarian Geological Society, vol. 82, part 3, 228-230, https:/doi.org/10.52215/ rev.bgs.2021.82.3.228.

Vidyalakshmi, R., R. Paranthaman, R. Bhakyaraj. 2009. Sulphur Oxidizing Bacteria and Pulse Nutrition - A Review. World Journal of Agricultural Sciences, 5, 3, 270-278.

Wang, Z., Y. Xu, Z. Zhang, Y. Zhang. 2021. Review: Acid Mine Drainage (AMD) in Abandoned Coal Mines of Shanxi, China. Water, 13, 8, https://dx.doi.org/10.3390/ w13010008.

Yang, Y., M. Wan, W. Shi, H. Peng, G. Qiu, J. Zhou, X. Liu. 2007. Bacterial diversity and community structure in acid mine drainage from Dabaoshan Mine, China. Aquatic microbial ecology, 47, 141-151, https://doi.org/10.3354/ame047141.

Zhang, Z., Z.Wang, Y. Xu, Y. Zhang, L. Guo, Q. Zheng, L. Tang. 2019. Quantitative study on the changes of karst groundwater level and hydrochemistry in Jinci Spring catchment, Shanxi, China. Expo Health, 12, 513-525, https://doi.org/10.1007/ s12403-019-00317-9.

Постьпила: 30.11 .2021

Приета: 20.12.2021
Received: 30 November 2021 Accepted: 20 December 2021 